\title{
Internet of things based learning media with problem solving approach: Its effect on higher order thinking skills
}

\author{
Yeni Rima Liana ${ }^{1 *}$, Suharto Linuwih ${ }^{2}$, Sulhadi $^{3}$ \\ ${ }^{1}$ Senior High School 2 Batang, in Batang Regency, Centra Java, Indonesia \\ 2,3 Physics Education Master's Program, Postgraduate, Universitas Negeri Semarang, Indonesia \\ *Corresponding Address: yrimaliana21@gmail.com
}

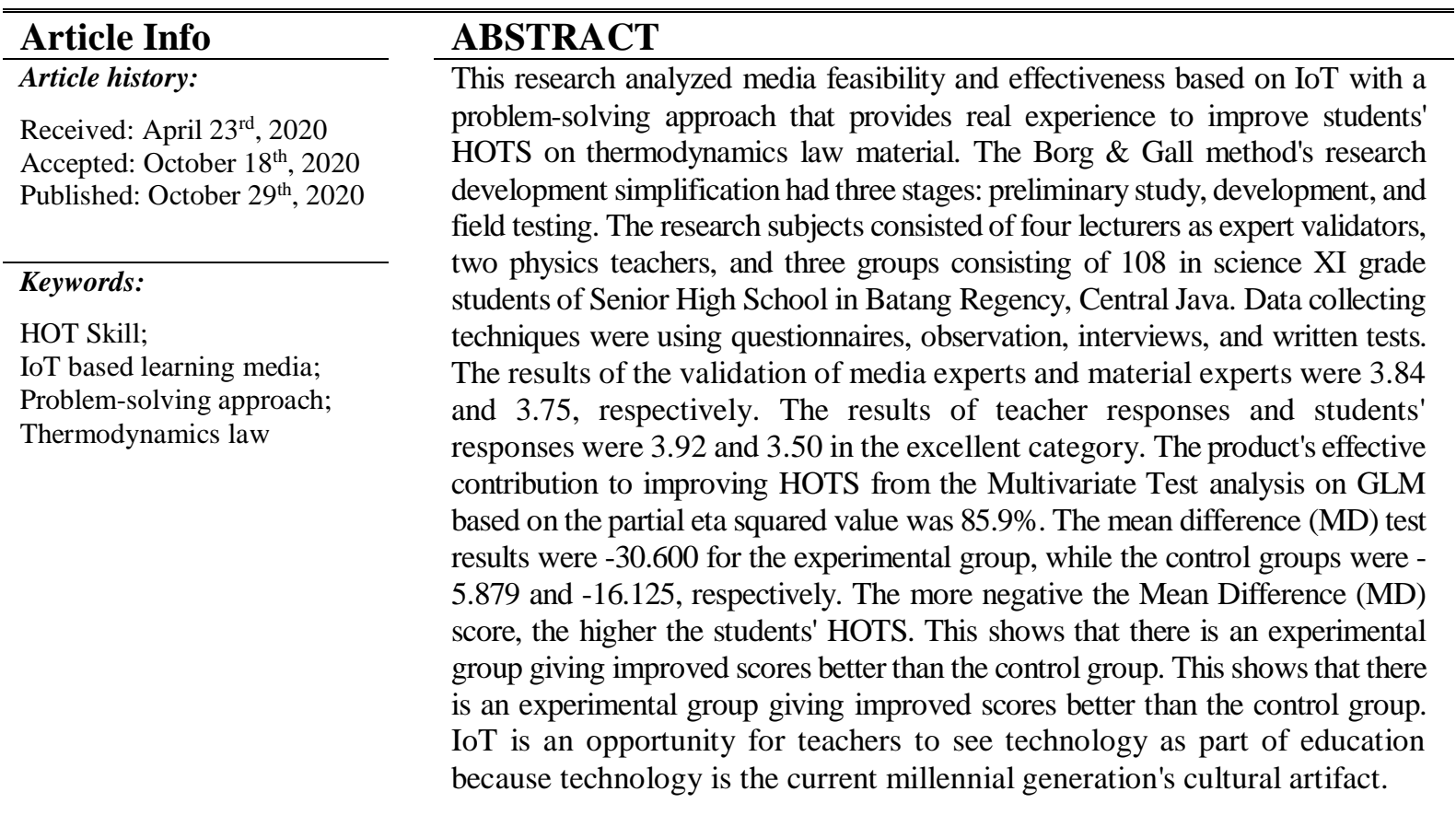

(C) 2020 Physics Education Department, UIN Raden Intan Lampung, Indonesia.

\section{INTRODUCTION}

Education in the industrial revolution era 4.0 was marked by the emergence of new literacy, namely data literacy, technological literacy, and human literacy (Zimmermann \& Torsten, 2018). The development of Information and Technology of the $21^{\text {st }}$ Century has entered the era of the Internet of Things (IoT) (Muchlis et al., 2017; Afrizal, 2018). IoT is a data transfer technology via the internet that connects various objects ('things') and does not require public IP on the client-side that can be accessed anytime and anywhere using a thingspeak server (He et al., 2016; Gómez et al., 2013). Thingspeak is a server dedicated to IoT devices that connect microcontrollers to the internet (Al Rikabi et al., 2020; Saputra \& Hertanto, 2018). Thingspeak can be used to create IoT projects and can be downloaded for free (Prihatmoko, 2016). The presence of IoT provides a new color in instructional media innovation (Artono \& Putra, 2017).

Opportunities for IoT need to be used more broadly in learning in schools (Muchlis et al., 2015). Physics learning media that utilize IoT can increase interest and motivation to learn and strengthen knowledge in full (Charmonman et al., 2020). Agreeing with this, Mohamed et al. (2018) state that IoT can improve the quality of the 
learning experience that enables real-time insights and performance. Students can visualize and process data uploaded using smartphone devices (Saraubon, 2019). This explanation concludes that the use of media in learning helps students learn about difficult and abstract physics material.

Data in the field shows that students are still weak in HOTS, such as analyzing, evaluating, and creating (Ariyana et al., 2019). This was revealed from the report on the results of the Computer-Based National Examination in 2019, namely, the most difficult physics material nationally is thermodynamics, with the number of students who answered correctly only $42.51 \%$ (Puspendik, 2019). Furthermore, based on observations and interviews with XII grade students of senior high school in the Batang Regency, the most difficult physics material in Computer-Based National Examination is thermodynamics.

Thermodynamics has various concepts, and some of them are very abstract, such as the concepts of heat and entropy (Hakim et al., 2017). Sari et al. (2013) research results state that most students have difficulty understanding the concept of entropy (the second law of thermodynamics). This causes difficulties in the learning process (Goovaerts et al., 2019). The application of android-based technology in collaboration with experiment learning can help teachers to overcome difficulties in visualizing abstract concepts (Religia \& Achmadi, 2017)

The observations at several secondary schools in Batang indicated the unavailability of a thermodynamic principle experiment media utilizing IoT. One foundational technology of IoT is the Radio-Frequency Identification (RFID) technology, which allows microchips to transmit the identification number of the objects to a reader through wireless communication. Through RFID technology, physical objects can be identified, tracked, and monitored automatically (Dasilva et al., 2019). The Research result of Muchlis et al. (2017) states that IoT enables students to observe automatic time measure- ment results and observational data through the Newton App application. Also, Gómez et al. (2013) and Afrizal (2018) state that IoTbased learning media effectively integrates all experimental devices into the network and can be managed from websites that can provide real-time information.

The obstacle that is often encountered by teachers is the problem of teaching time. The lack of time to do practical work is the main obstacle for teachers because most of the teachers' time is used to pursue teaching materials (Malik et al., 2019). Judging from the conditions or facts on the ground, it does not fulfill the expected competencies and learning objectives in the 2013 curriculum (Georgiou, 2014; Saputro et al., 2019). Besides, students' lack of opportunities to have real experience and active learning through experiment activities, especially thermodynamic law (Georgious \& Sharma, 2015; Layali \& Kartika, 2015). The use of android-based technology, combined with experiment learning, can help teachers overcome the difficulties in visualizing abstract concepts (Religia \& Achmadi, 2017)

The above research facts indicate that it is necessary to develop learning media following technological developments in the industrial revolution era 4.0 as a means to attract students' learning interest. Opportunity of IoT as a learning media has become one of the technologies currently considered by teachers and students. Even more that the millennial generation is a digital generation that is technologically literate and likes to linger with smartphones, laptops and gadgets. This IoT-based learning media is very effective to use in learning because the experimental data obtained can be accessed in real time by students in graphic form via smartphones sent by Arduino clients. Students can directly analyze the parameters of the experimental results and the teacher can also control the experimental activities of all groups of students through the Thing Speak server. Experimental data can be stored in a smartphone that can be opened anytime and 
anywhere. The application of problem solving in experimental activities is expected to improve the skills of $4 \mathrm{C}$ (critical thinking, communication, collaboration, and creativity) and HOTS students to analyze, evaluate and create thermodynamics law material.

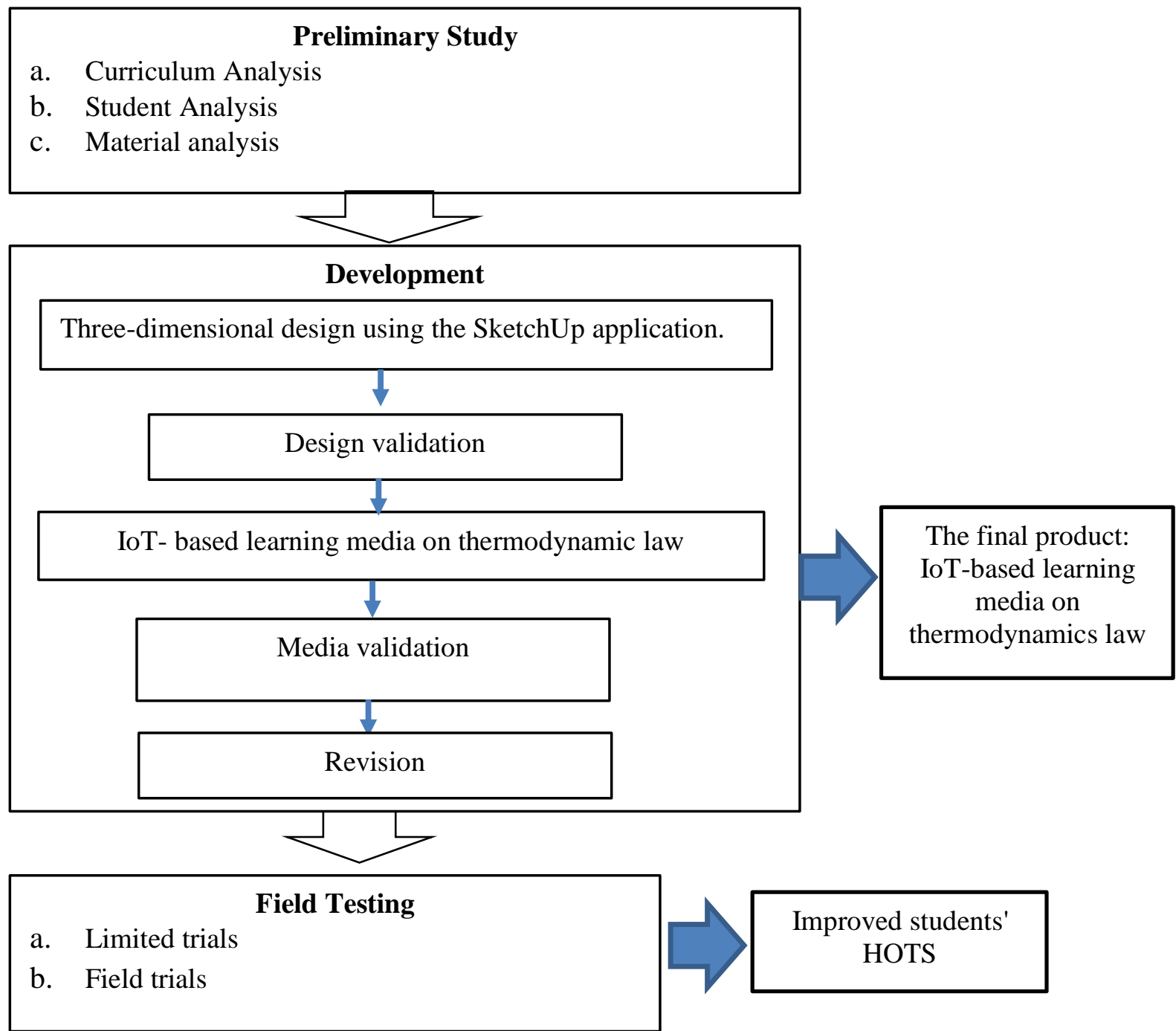

Figure 1. Stages of IoT-based learning media development integrated with a problem-solving approach

\section{METHODS}

This research was a research and development using a procedure proposed by Borg \& Gall (2003). The procedure consisted of three simplified stages: a preliminary study, development, and field testing. The factors underlying this simplification are the limited time, cost, and similarity of stages.

The research subjects consisted of four lecturers as expert validators, two physics teachers, and three groups consisting of 108 eleventh-grade science students of Senior High
School in Batang Regency. At the same time, the subject of dissemination was the senior high school Teacher's Meeting of Physics Subjects (MGMP) in Batang, Central Java.

Data collection techniques used were nontest and test. Data collection instruments include observation sheets, validation questionnaires for media experts and material experts, teacher response questionnaires, student questionnaire responses, and HOTS tests. The data analysis technique of the media feasibility assessment results is based 
on expert validation results, teacher responses, and students' responses using assessments in the range of scores from 1 to 4. The average score was calculated based on the total score of all aspects of the assessment divided by the number of evaluators.

$$
\bar{X}=\frac{\sum X}{n}
$$

(Widoyoko, 2017)

To convert the data to scaled standard scores (Widoyoko, 2017) ideal assessment criteria are used that can be seen in Table 1,

Table 1. Ideal assessment criteria (Widoyoko, 2017)

\begin{tabular}{ccc}
\hline Score Range & Categories & Indeks \\
\hline $\bar{X} \geq X_{i}+1.8 \mathrm{Sbi}$ & Excellent & 5 \\
$X_{i}+0.6 \mathrm{Sbi}<\bar{X} \leq X_{i}+1.8 \mathrm{Sbi}$ & Good & 4 \\
$X_{i}-0.6 \mathrm{Sbi}<\bar{X} \leq X_{i}+0.6 \mathrm{Sbi}$ & Fair good & 3 \\
$X_{i}-1.8 S b i<\bar{X} \leq X_{i}-0.6 \mathrm{Sbi}$ & Less & 2 \\
$\bar{X} \leq X_{i}-1.8 \mathrm{Sbi}$ & Very Less & 1 \\
\hline
\end{tabular}

$\bar{X}$ is the mean score, $X_{i}$ is the mean ideal score $=1 / 2$ (maximum score + minimum score), and $S b i$ is the ideal standard deviation of score $=1 / 6$ (maximum score - minimum score).

The research design used is the PretestPosttest Control Group Design, which can be seen in Table 2.

Table 2. Research design

\begin{tabular}{cccc}
\hline \multirow{2}{*}{ Group } & Pretest & \multirow{2}{*}{ Treatment } & Posttest \\
\cline { 2 - 2 } & $\mathrm{Y}$ & & $\mathbf{Y}$ \\
\hline Experiment & $\mathrm{T}_{1}$ & $\mathrm{X}_{1}$ & $\mathrm{~T}_{2}$ \\
Control 1 & $\mathrm{T}_{1}$ & $\mathrm{X}_{2}$ & $\mathrm{~T}_{2}$ \\
Control 2 & $\mathrm{T}_{1}$ & $\mathrm{X}_{3}$ & $\mathrm{~T}_{2}$ \\
\hline
\end{tabular}

$\mathrm{T}_{1}$ is a pretest, $\mathrm{T}_{2}$ is a posttest, $\mathrm{Y}$ is HOTS, $\mathrm{X}_{1}$ is the group using IoT-based learning media, $\mathrm{X}_{2}$ is the group using multimedia based on Android, and $X_{3}$ is the group using the teacher general module.

An assumption test was first analyzed to determine the effectiveness of the IoT-based learning media, consisting of normality tests and students' pretest and posttest data homogeneity. The normality test is carried out based on Kolmogorov-Smirnov statistics.
The sample comes from a normally distributed population if the significance value is more than 0.05 . At the same time, the homogeneity test determines whether the sample used has the same variance or not. The sample used in the study was said to be homogeneous if it obtained a significance value (Sig.) greater than 0.05 based on Levene's test.

After the assumption test has been fulfilled, then the Multivariate Test analysis is performed on the mixed design General Linear Model (GLM) based on the partial eta squared value to test the media's effectiveness based on the results of the pretest and posttest. IoT based learning media effectively improve students' HOTS if the Sig value $<0.05$.

\section{RESULTS AND DISCUSSION Preliminary Study}

The preliminary study is the stage that identifies what teachers and students need in learning physics and to identify problems that in the field are directly complained of by teachers and high school students. This stage consists of three aspects, needs analysis, curriculum analysis, and material analysis (Yono et al., 2016). Based on the needs analysis, students have not been provided with a thermodynamic principle experiment media. The thermodynamics law theory material has not yet applied the experimental method with a problem-based learning approach.

The 2013 curriculum demands teachers to become facilitators, motivators, and inspirators for students in the process of finding their knowledge, including the transfer process, level of understanding, ability to predict, problem-solving, and translating process (Holme et al., 2015). Implementation of the 2013 curriculum uses three learning models that are expected to advance scientific and social behavior and develop a sense of curiosity. The three models are: (1) Discovery/Inquiry Learning Model, (2) Problem-Based Learning Model (3) Project-Based Learning Model (Subali et 
al., 2019). Based on the high school physics curriculum analysis, Basic Competency 4.7 in thermodynamic law theory is supposed to make a work/model of the first and second thermodynamics application laws and their physical meaning (Kemdikbud, 2016). This requires teachers to be creative and innovative in creating learning media to guide students in observing the phenomenon of thermodynamic law through real experiments. Therefore, to required learning media, which provides real experiments to enable students to observe thermodynamic laws directly (Tatar \& Oktay, 2011).

\section{Development}

The process of developing IoT based learning media products is divided into five parts, namely:

\section{(a) Hot and Cold Body Reservoir}

Hot and cold reservoirs are made of acrylic with a length of $30 \mathrm{~cm}$, width $15 \mathrm{~cm}$, height $20 \mathrm{~cm}$, and $5 \mathrm{~mm}$ thickness. Both reservoirs are equipped with a ruler to measure the height of the inserted water. Diathermal insulation that separates the two reservoirs is made of Aluminum Composite Panel (ACP) with dimensions of length $20 \mathrm{~cm}$, width $15 \mathrm{~cm}$, and thickness of $2.5 \mathrm{~mm}$ connected in series with eight TEG SP184827145 peltiers. The TEG Peltier is to convert heat energy into electrical energy due to the temperature difference between the two reservoirs. Cold reservoir walls are equipped with pipes to facilitate water discharge. The top of the two reservoirs is closed with ACP, equipped with a hole to put the heater and insert two DS18B20 temperature sensors.

\section{(b) Electrical Body Components}

The front's electrical components consist of LCDs, TEG sockets, Jumper cables for TEG 1, TEG 2, TEG 3, and TEG 4, sockets lamp sockets, 12V DC, LED lamp fittings, Jumper cables for light sockets. In comparison, the rear electrical component consists of $220 \mathrm{~V}$ AC sockets, on/off buttons, temperature control buttons, temperature sensor sockets that are colored yellow, red, and black, water heater sockets, TEG sockets, JST Port TEG 1, TEG 2, TEG 3 dan TEG 4, and 5V DC output terminals for circulating water pumps.

\section{(c) Microcontroller Components}

The microcontroller components consist of: (1) 830-point breadboard, (2) Arduino Nano version 3.0, (3) ESP8266-01 wifi module, (4) 3.3 Volt AMS, (5) voltage sensor, (6) 5V adapter; 3A, (7) USB cable, (8) NYAF $2.5 \mathrm{~mm}$ cable, male to female jumper cable, resistor as shown in Figure 2.

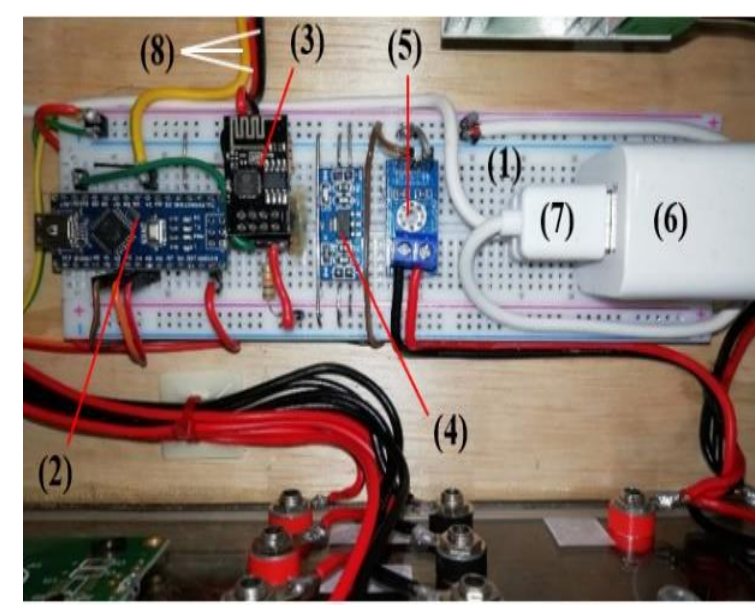

Figure 2. The microcontroller components
(d) Experiments Guide and Student Work- sheet

This media is equipped with IoT guidelines based on thermodynamic experiments and Student Worksheets, which contain instructions for the use, procedures, and practicum of the zero-thermodynamic law, the first law of thermodynamics, and the second law of thermodynamics such as Figure 3. 


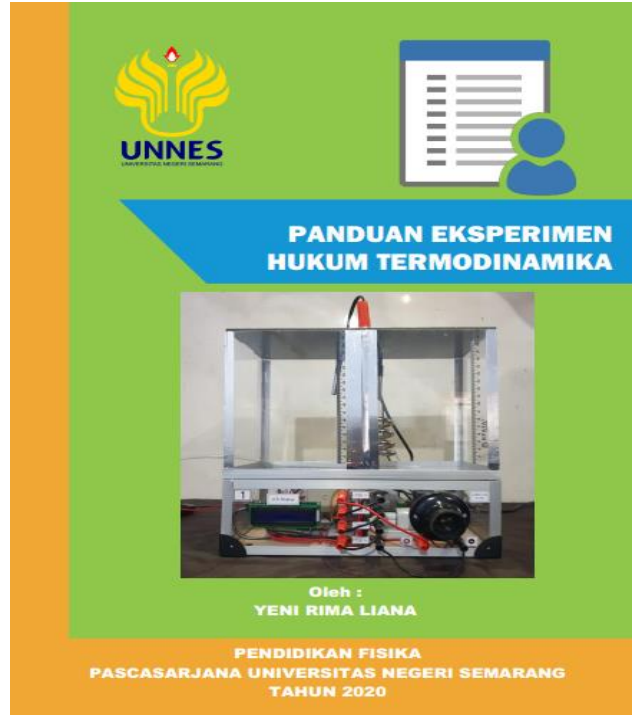

Figure 3. IoT based learning media guide

The process of developing IoT based learning media is based on the characteristics of the feasibility of instructional media, which are durable (made of strong enough material), attractive shapes and colors, simple and easy to use (uncomplicated), can explain concepts, according to learning objectives, and can be the basis of problemsolving. The product design is then realized, which is to create an IoT-based learning media to study the laws of thermodynamics, as shown in Figure 4.

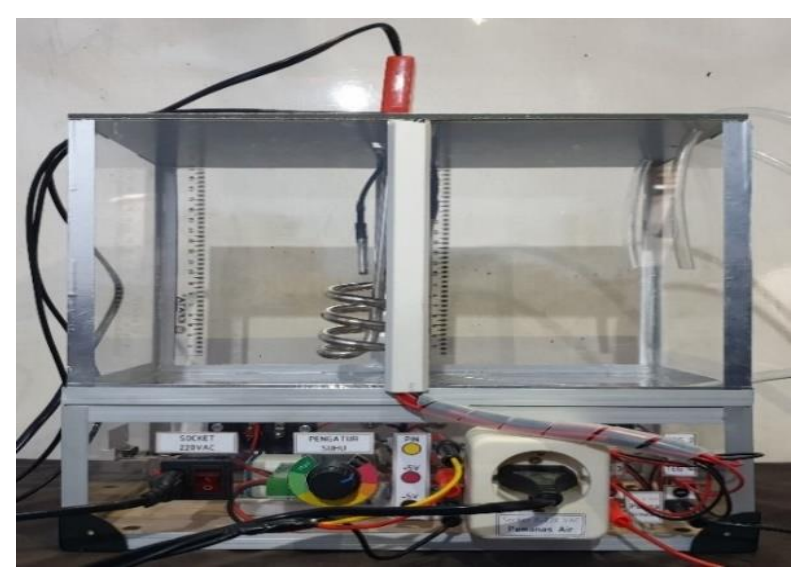

Figure 4. The rear IoT based learning media

(e) IoT server (ThingSpeak)

It sets up an IoT server (ThingSpeak) to receive data from the publisher (Arduino), save the data, and display it in graphical form. The first step to creating an account and channel on ThingSpeak.com is to open https://thingspeak.com and click the SignUp tab.

Then create a data channel by filling in the required fields (one channel max eight fields); the minimum that must be filled in is the channel name ('Name') and 'field1' (check the 'Make Public' option if your data you want to be seen by others) Then press the 'Save Channel' button shown in figure 5.

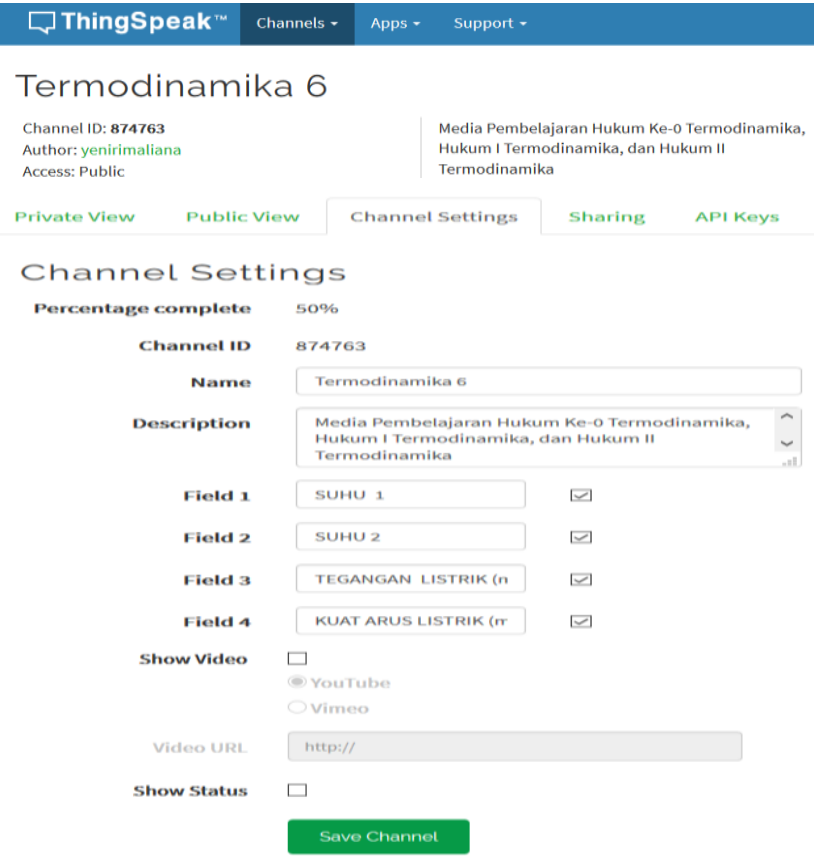

Figure 5. Creating data channels 


\section{Product validation Results}

The IoT based learning media that has been revised was validated by four expert judgments $(2$ material experts and 2 media experts) and 2 professional physics teachers. Each expert was given a questionnaire sheet containing statements relating to the media's suitability, reviewed from the aspect of the media and material aspects. Data obtained from the assessment of IoT based learning media was in ranges of 1 to 4 . The average score of each item for all aspects of product evaluation is calculated based on the total score of all aspects of assessment divided by the number of judgments. After that, the criteria' average score is converted into categories by using the five-scale grading criteria technique.

The product evaluation results based on the media aspect and material aspect were analyzed using a standard five-scale assessment category and categorized according to Table 3 (Widoyoko, 2017).

Table 3. Feasibility criteria for assessment standard five- scale

\begin{tabular}{cc}
\hline Range of Scores & Category \\
\hline $\bar{X}>3,4$ & Very good \\
\hline $2.8<\bar{X} \leq 3.4$ & Good \\
\hline $2.2<\bar{X} \leq 2.8$ & Fair \\
\hline $1.6<\bar{X} \leq 2.2$ & Less good \\
\hline $\bar{X} \leq 1.6$ & Not good \\
\hline
\end{tabular}

The assessment of experiment media based on IoT based on media aspects was carried out by two media expert lecturers and two professional physics teachers (practitioners). The product evaluation results based on material aspects were analyzed using a five-scale standard assessment category and categorized according to Table 4 . The analysis results are presented in Table 4.

Table 4. Results of analysis of feasibility assessment of IoT based learning media according to media experts

\begin{tabular}{lcccc}
\hline \multicolumn{1}{c}{ Aspect } & Item & $\begin{array}{c}\text { Average } \\
\text { Per } \\
\text { Item }\end{array}$ & $\begin{array}{c}\text { Average } \\
\text { Per } \\
\text { Aspect }\end{array}$ & Category \\
\hline $\begin{array}{l}\text { The } \\
\text { resilience }\end{array}$ & 1 & 4.00 & 4.00 & $\begin{array}{c}\text { Very } \\
\text { Good }\end{array}$ \\
\hline
\end{tabular}

\begin{tabular}{|c|c|c|c|c|}
\hline Aspect & Item & $\begin{array}{c}\text { Average } \\
\text { Per } \\
\text { Item }\end{array}$ & $\begin{array}{c}\text { Average } \\
\text { Per } \\
\text { Aspect }\end{array}$ & Category \\
\hline \multicolumn{5}{|l|}{$\begin{array}{l}\text { of the } \\
\text { media } \\
\text { component }\end{array}$} \\
\hline \multirow{2}{*}{$\begin{array}{l}\text { Ease of } \\
\text { conducting } \\
\text { an } \\
\text { experiment }\end{array}$} & 2 & & \multirow{2}{*}{4.00} & \multirow{2}{*}{$\begin{array}{l}\text { Very } \\
\text { Good }\end{array}$} \\
\hline & 3 & 4.00 & & \\
\hline \multirow{2}{*}{$\begin{array}{l}\text { Sensor } \\
\text { accuracy }\end{array}$} & 4 & 3.50 & \multirow{2}{*}{3.50} & \multirow{2}{*}{$\begin{array}{l}\text { Very } \\
\text { Good }\end{array}$} \\
\hline & 5 & 3.50 & & \\
\hline \multirow{2}{*}{$\begin{array}{l}\text { Ease of } \\
\text { reading } \\
\text { experiment } \\
\text { result data }\end{array}$} & 6 & 4.00 & \multirow{2}{*}{3.88} & \multirow{2}{*}{$\begin{array}{l}\text { Very } \\
\text { Good }\end{array}$} \\
\hline & 7 & 3.75 & & \\
\hline \multirow{2}{*}{$\begin{array}{l}\text { Ease of } \\
\text { care }\end{array}$} & 8 & 4.00 & \multirow{2}{*}{3.88} & \multirow{2}{*}{$\begin{array}{l}\text { Very } \\
\text { Good }\end{array}$} \\
\hline & 9 & 3.75 & & \\
\hline $\begin{array}{l}\text { Safety for } \\
\text { student }\end{array}$ & 10 & 4.00 & 4.00 & $\begin{array}{l}\text { Very } \\
\text { Good }\end{array}$ \\
\hline \multirow[t]{2}{*}{ Aesthetics } & 11 & 4.00 & \multirow{2}{*}{4.00} & \multirow{2}{*}{$\begin{array}{l}\text { Very } \\
\text { Good }\end{array}$} \\
\hline & 12 & 4.00 & & \\
\hline Efficient & 13 & 3.50 & 3.50 & $\begin{array}{l}\text { Very } \\
\text { Good }\end{array}$ \\
\hline \multicolumn{3}{|c|}{ Average of All Aspects } & 3.84 & $\begin{array}{l}\text { Very } \\
\text { Good }\end{array}$ \\
\hline
\end{tabular}

The assessment results obtained are quantitative data with a score of 1 to 4 . This data is then converted and analyzed using a five-scale rating category, as in Table 4. Product evaluation based on sub-aspects of sensor accuracy and experiment time efficiency in Table 5 using a scale 5 rating category gets a value average of 3.50 , classified as an outstanding category. Ratings provided by the validator are included with suggestions for improvement. Suggestions for improvement given by the validator include the socket is designed more friendly so that it is easily installed and removed by students so that the experiment time is more efficient and does not affect the sensor's sensitivity. The reading ease of experiment results on ThingSpeak obtained a mean value of 3.75 and was classified as an outstanding category. Suggestions for improvement given by the validator are that it must be stable when conducting internet network experiments. The overall analysis of all aspects obtained a mean value of 3.81 and showed that IoT based learning media 
developed were included in the excellent category. These results prove that the IoT based learning media is appropriate to be used in physics learning activities. The analysis results are presented in Table 5 .

Table 5. IoT based learning media feasibility assess-

\begin{tabular}{|c|c|c|c|c|}
\hline Aspect & Item & $\begin{array}{c}\text { Average } \\
\text { Per } \\
\text { Item }\end{array}$ & $\begin{array}{c}\text { Average } \\
\text { Per As- } \\
\text { pect }\end{array}$ & Category \\
\hline \multirow{4}{*}{$\begin{array}{l}\text { Media suita- } \\
\text { bility with } \\
\text { curriculum } \\
\text { analysis and } \\
\text { requirement } \\
\text { analysis }\end{array}$} & 1 & 3.75 & \multirow{4}{*}{3.81} & \multirow{4}{*}{$\begin{array}{l}\text { Very } \\
\text { Good }\end{array}$} \\
\hline & 2 & 4.00 & & \\
\hline & 3 & 3.75 & & \\
\hline & 4 & 3.75 & & \\
\hline \multirow{2}{*}{$\begin{array}{l}\text { Conformity } \\
\text { of media } \\
\text { with material }\end{array}$} & 5 & 4.00 & \multirow[b]{2}{*}{3.75} & \multirow[b]{2}{*}{$\begin{array}{l}\text { Very } \\
\text { Good }\end{array}$} \\
\hline & 6 & 3.50 & & \\
\hline \multirow{4}{*}{$\begin{array}{l}\text { Media up- } \\
\text { date on Stu- } \\
\text { dent problem } \\
\text { solving and } \\
\text { enhance } \\
\text { meet stu- } \\
\text { dent's HOTS }\end{array}$} & 7 & 3.75 & \multirow{4}{*}{3.69} & \multirow{4}{*}{$\begin{array}{l}\text { Very } \\
\text { Good }\end{array}$} \\
\hline & 8 & 4.00 & & \\
\hline & 9 & 3.75 & & \\
\hline & 10 & 3.25 & & \\
\hline \multicolumn{3}{|c|}{ Average of All Aspects } & 3.75 & $\begin{array}{c}\text { Very } \\
\text { Good }\end{array}$ \\
\hline
\end{tabular}

Assessment of IoT based learning media on aspects of curriculum analysis and needs analysis in Table 5 using a scale five assessment category obtained a mean value of 3.81, classified as an outstanding category. Ratings provided by the validator are included with suggestions for improvement. Suggestions for improvement provided by the validator include researchers adding necessary competency skills. The media's suitability with learning material obtained an average value of 3.75 and is classified as an excellent category. Suggestions for improvement given by the validator need to be explained that water can represent the ideal gas system. In the problem-solving aspect, the mean score was 3.69 and classified as an excellent category. Suggestions for improvement given by the validator are that researchers are asked to improve the experiment's steps in detail so that it is easy for students to understand. The overall analysis of all aspects obtained a mean value of 3.75 and showed that IoT based learning media developed were included in the excellent category. These results prove that the IoT based learning media with the problem-based learning approach is suitable for use in physics learning activities.

\section{Students' Responses}

This limited trial aims to find out the students' responses to the thermodynamic experimental media based on IoT which were previously revised based on the results of expert validation. The ease of carrying out experiments is based on aspects of learning, experimental guidelines, and experimental data obtained. During the learning process, students use experimental media to learn thermodynamics. Researchers observe students' attitudes toward the product being developed and guide if problems arise in media use. After completing the experimental activities, students fill out a questionnaire about thermodynamics law experiment media-based IoT. Researcher observations and the results of student responses during the limited trial activities are presented in Table 6 .

Table 6. Students' responses to limited trials

\begin{tabular}{lccc}
\multicolumn{1}{c}{ Aspect } & $\begin{array}{c}\text { Number of } \\
\text { participants }\end{array}$ & $\begin{array}{c}\text { Average } \\
\text { per as- } \\
\text { pect }\end{array}$ & Category \\
\hline $\begin{array}{l}\text { Learning } \\
\begin{array}{l}\text { Experimental } \\
\text { guidelines } \\
\text { thingspeak } \\
\text { data }\end{array}\end{array}$ & 6 & 3.76 & \\
\hline
\end{tabular}

Table 6 shows the average value of the learning aspect of 3.76, which is included in the excellent category. The experimental guidance aspect obtained an average of 3.50 with an excellent category and the ThingSpeak data aspect of 3.24 with a good category. Suggestions from students 
regarding IoT-based experimental media improve the TEG socket so that it is easier to insert the jumper cable. Overall, student assessment of IoT based learning media is included in the excellent category, so the product is suitable for use in physics learning activities with a problem-solving approach.

\section{Field Testing}

The implementation of field trials was carried out at Senior High School in Batang Regency with a sample of 36 students from 108 in science XI grade students. Thirty-six experimental group students used IoT-based learning media, 36 students in control group 1 used Android-based multimedia. As many as 36 students in control group 2 used the general module of the teacher.

Experimental group field trials were carried out through thermodynamic law experiment activities with a problem-solving approach. The stages of problem-solving skills start from preparing a lesson plan according to the Problem Based Learning model's syntax like Figure 6.

\begin{tabular}{|c|c|c|}
\hline Preliminary & Core activities & Closing \\
\hline $\begin{array}{l}\text { - Teachers do the } \\
\text { opening with opening } \\
\text { greetings and pray to } \\
\text { start learning, } \\
\text { examine the presence } \\
\text { of students as a } \\
\text { disciplinary attitude, } \\
\text { prepare students } \\
\text { physically and } \\
\text { psychologically in } \\
\text { initiating learning } \\
\text { activities and literacy. } \\
\text { - Inform the learning } \\
\text { objectives, } \\
\text { thermodynamic law } \\
\text { experiment activities } \\
\text { carried out by students } \\
\text { and motivate students } \\
\text { related to the benefits } \\
\text { of learning } \\
\text { thermodynamics in } \\
\text { everyday life. }\end{array}$ & $\begin{array}{l}\text { - Student orientation on the problem } \\
\text { Students are facilitated by teacher } \\
\text { discussing the laws that underlie } \\
\text { thermodynamics } \\
\text { - Organizing students to learn } \\
\text { The teacher divides the class into } 6 \text { groups } \\
\text { to carry out the activities of the zero law } \\
\text { experiment, I and II thermodynamics. } \\
\text { - Guiding individual and group } \\
\text { investigations } \\
\text { Students are facilitated by the teacher to } \\
\text { carry out the activities of the zero law } \\
\text { experiment, law I and law II } \\
\text { thermodynamics. } \\
\text { - Develop and present the work } \\
\text { Students write the results of experiments } \\
\text { and present the results of work and } \\
\text { discussions relating to the zero law, I and II } \\
\text { thermodynamics. } \\
\text { - Analyze and evaluate the problem solving } \\
\text { process } \\
\text { Each group made a presentation, the other } \\
\text { groups gave their appreciation. Make } \\
\text { conclusions in accordance with input } \\
\text { obtained from other groups. }\end{array}$ & 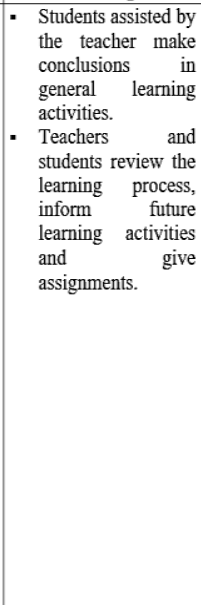 \\
\hline
\end{tabular}

Figure 6. Learning activities with problem-based learning models

Through the problem-solving approach with the Problem Based Learning model, students are divided into six experimental groups with the names Thermodynamics 1 to Thermodynamics 6. Students go to the website https://thingspeak.com/channels/channel. Channel IDs are filled in according to groups 924020, 924021, 924024, 944777, 944778, and 874763, as shown in Figure 7. All students in groups actively participate in experiment activities that will foster HOTS as critical and creative thinking skills to establish communication and collaboration between students.

\section{https:/thingspeak.com/channels/874763 \\ Q Semua Q Video 国 Berita 0 Gambar $\odot$ Maps : Lainnya \\ 3 hasil (0,30 detik) \\ api.thingspeak.com > channels $>874763$ \\ Termodinamika 6 - ThingSpeak I0T \\ ... Termodinamika 6 on ThingSpeak - ThingSpeak is the open loT platform \\ analytics. ... Channel ID: 874763; Author: yenirimaliana; Access: Public.}

Figure 7. ThingSpeak IoT website views

Following syntax, each group can monitor the experiments' results on the ThingSpeak.com application, then select the channel settings and public view (heat temperature vs. time, cold temperature vs. time, voltage vs. time, and electric current vs. time) as shown in figure 8. After the data was obtained, students analyze the data to calculate the heat released by the heat reservoir and the heat received by the cold reservoir, the electrical energy generated by the heat converter, the change in the system's internal energy, and the efficiency of the converter. 


\section{$\square$ ThingSpeak" Channels - Apps- Support- Commercial Use How to Buy Account. Sign out}

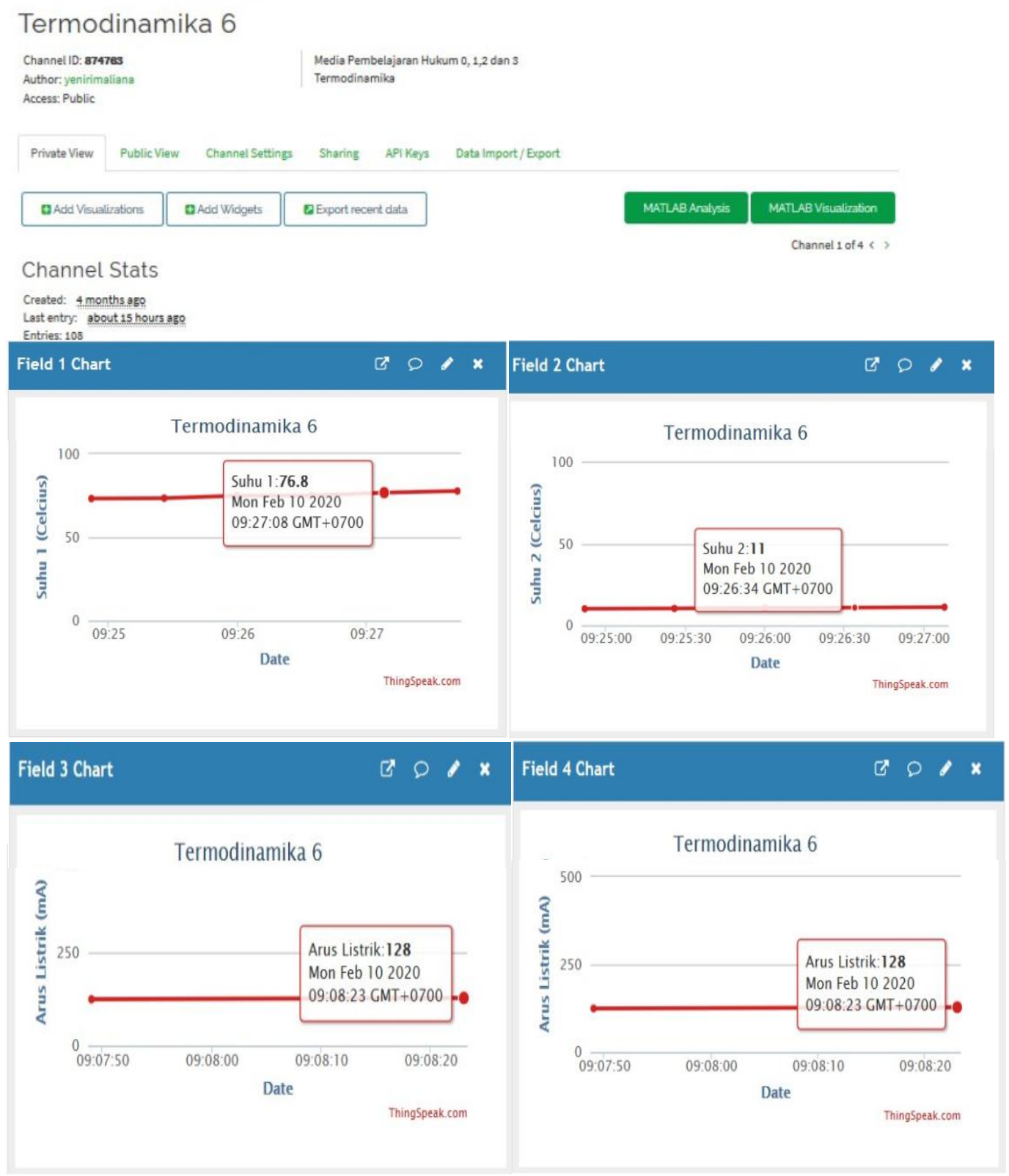

Figure 8. Public view thingspeak graph on smartphone

In closing the experiment, students are guided by the teacher to conclude from the results of the zero-law thermodynamics experiment, the first thermodynamics, and the second law thermodynamics, the principle of heat converter work, and the efficiency of the converter.

The field trial aims to determine the effectiveness of IoT based learning media in increasing students' HOTS. Data from the test results in the field are learning outcomes based on students' cognitive abilities, namely learning outcomes, analyzing, evaluating, and creating. Field testing is done by applying three steps, namely pretest, treatment, and posttest. The results are presented in Table 7. 
Table 7. HOTS test result

\begin{tabular}{cccc}
\hline Component & Class & Average & $\begin{array}{c}\text { Standard } \\
\text { Deviation }\end{array}$ \\
\hline Pretest & Experiment & 40.71 & 3.81 \\
& Control 1 & 45.15 & 5.59 \\
& Control 2 & 40.31 & 2.44 \\
Post-test & Experiment & 71.31 & 5.22 \\
& Control 1 & 51.03 & 7.55 \\
& Control 2 & 56.44 & 8.27 \\
\hline
\end{tabular}

Students' HOTS test results for the experimental class and control class 1, and control class 2 are presented in Table 7. Table 7 shows that student's HOTS increase after using the IoT based learning media.

To determine the effectiveness of the IoT based learning media in increasing students' HOTS, a multivariate test statistic test was analyzed on the Mixed Linear General Model (GLM) based on partial eta squared values. Before conducting statistical tests related to the research hypotheses, the prerequisites are assumption tests consisting of normality tests and homogeneity of the students' pretest and post-test results data.

Table 8. Results of the normality test analysis

\begin{tabular}{cllll}
\hline \multirow{2}{*}{ Test } & \multirow{2}{*}{ Class } & \multicolumn{3}{l}{ Kolmogorov-Smirnov } \\
\cline { 3 - 5 } & & Statistics & df & Sig. \\
\hline \multirow{2}{*}{ Pretest } & Experiment & 0.12 & 30 & 0.20 \\
HOTS & Control 1 & 0.15 & 32 & 0.06 \\
& Control 2 & 0.14 & 30 & 0.12 \\
\multirow{2}{*}{ Posttest } & Experiment & 0.15 & 30 & 0.08 \\
HOTS & Control 1 & 0.13 & 32 & 0.17 \\
& Control 2 & 0.15 & 30 & 0.08 \\
\hline
\end{tabular}

Table 8 shows the results of the normality test based on Kolmogorov-Smirnov statistics on the sample used. The results of the analysis of Table 9 shows the significance value (Sig.) For each variable greater than 0.05 ( $p>0.05)$, the sample used in the study came from normally distributed populations.

The next assumption test is the homogeneity test. A homogeneity test is performed to determine whether the sample used has the same variance or not. Homogeneity test results are presented in Table 9.
Table 9. Homogeneity test analysis results

\begin{tabular}{cllll}
\hline Tes & F & df1 & df2 & Sig. \\
\hline Pretest HOTS & 0.07 & 2 & 89 & 0.93 \\
Posttest HOTS & 0.02 & 2 & 89 & 0.98 \\
\hline
\end{tabular}

Table 9 shows the homogeneity test results based on Levene's statistical test. The results of the analysis in Table 10 show a significance value (Sig.) for each variable greater than $0.05(\mathrm{p}>.05)$.

Data analysis to test student's HOTS improvement is to use the General Linear Model (GLM). The analysis was carried out based on the students' pretest and posttest scores in doing HOTS tests by interpreting Mean Difference (MD) and significance (Sig.) outputs on pairwise comparisons output. The results of the analysis are presented in Table 10.

Table 10. Pairwise comparisons HOTS

\begin{tabular}{lcccc}
\multicolumn{1}{c}{ Group } & $\begin{array}{c}\text { Time } \\
(\mathbf{I})\end{array}$ & $\begin{array}{c}\text { Time } \\
(\mathbf{J})\end{array}$ & $\begin{array}{c}\text { Mean } \\
\text { Difference } \\
(\mathbf{I}-\mathbf{J})\end{array}$ & Sig. \\
\hline $\begin{array}{l}\text { IoT-based } \\
\text { learning } \\
\text { media }\end{array}$ & Pretest & Posttest & -30.600 & 0.000 \\
$\begin{array}{l}\text { Multimedia } \\
\text { based on }\end{array}$ & Pretest & Posttest & -5.879 & 0.000 \\
$\begin{array}{l}\text { Android } \\
\text { Teacher } \\
\text { general } \\
\text { module }\end{array}$ & Pretest & Posttest & -16.125 & 0.000 \\
\hline
\end{tabular}

Table 10 in the significance column (Sig.) Obtained a value of 0,000 , which proves a significant change in the HOTS of students in the classroom using IoT-based experimental media, interactive multimedia based on Android, and the teacher general module. Mean difference (MD) is obtained from reducing the mean pretest score against the posttest score. The increasingly negative MD values in Table 10 prove that there is a significant increase in the HOTS of students based on pretest and posttest scores. The pairwise comparisons output proves that classes using IoT-based learning media provide improved scores compared to multimedia based on Android and general teacher modules groups. 
The significant contribution of the use of IoT based learning media, android-based interactive multimedia, and general teacher modules in learning activities as a means for enhancing students' HOTS on thermodynamics law material can be seen from the results of the Multivariate Test analysis on GLM based on partial eta squared values in Table 11.

Table 11. Multivariate HOTS Tests

\begin{tabular}{lccc}
\multicolumn{1}{c}{ Class } & Sig. & $\begin{array}{c}\text { Partial Eta } \\
\text { Squared }\end{array}$ \\
\hline $\begin{array}{l}\text { IoT-based } \\
\text { learning me- } \\
\text { dia }\end{array}$ & $\begin{array}{c}\text { Hotelling's } \\
\text { trace }\end{array}$ & 0.00 & 0.86 \\
$\begin{array}{l}\text { Android- } \\
\text { based inter- } \\
\text { active multi- } \\
\text { media }\end{array}$ & $\begin{array}{c}\text { Hotelling's } \\
\text { trace }\end{array}$ & 0.00 & 0.18 \\
$\begin{array}{l}\text { Teacher } \\
\text { general } \\
\text { module }\end{array}$ & $\begin{array}{c}\text { Hotelling's } \\
\text { trace }\end{array}$ & 0.00 & 0.61 \\
\hline
\end{tabular}

The improvement in students' HOTS can be seen based on the Estimated Marginal Means plot graph. The plot for students' HOTS improvement is presented in Figure 9.

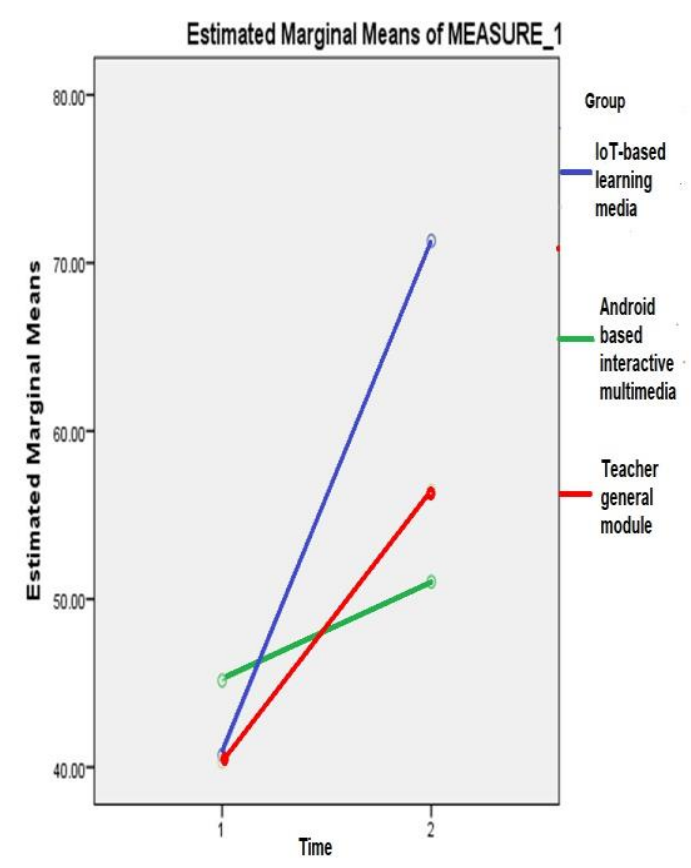

Figure 9. Chart of estimation of students' HOTS increase
The intersection of lines between classes using IoT based experiment media with Android-based interactive multimedia and standard modules used by the teacher in Figure 6 shows an interaction between IoT based experiment media with Android-based interactive multimedia and standard modules used by the teacher. This shows the influence generated between classes. The interaction causes include several students in the control class (Android based interactive multimedia class or Teacher general module) asking the experimental class students about the learning material.

The effectiveness of the IoT-based learning media in this study agrees with the research Dinatha \& Kua (2019) results, which states that digital practicum with Nature of Science (NOS) modules can increase HOTS in chemical practicum. Besides, applying a scientific approach using booklet media effectively increases the HOTS of students (Yani et al., 2018). This is also in line with the research results by Purnamawati et al. (2017) state that learning media in the form of inquiry-based student worksheets can improve higher-order thinking skills.

\section{CONCLUSION AND SUGGESTION}

Based on the results of the validation by expert validators and professional physics teachers, it can be concluded that IoT-based learning media that is fit to be used as a physics learning media to improve students' HOTS on thermodynamic principle material with the following characteristics: (1) using the ATmega328 microcontroller board as a data store, (2) the experimental data in the form of measurements temperature, electric current, and electric voltage can be read digitally on LCD displays, (3) graphs of data logging on experimental results can be accessed using smartphone with the link https://thingspeak.com/channels/ channelsID (4) equipped with a thermodynamics law experiment guide book with the HOTS approach as a problem solving. The effectiveness of IoT based learning media 
can be seen from the results of the Multivariate Test analysis on GLM based on the partial eta squared values obtained that the experimental class gives the highest percentage to improve students' HOTS, and the Estimated Marginal Means plot graph shows that there is an interaction between the experimental groups and control groups. The more negative the Mean Difference (MD) score proves, there is a significant increase in the HOTS. This shows that there is an experimental group giving improved scores better than the control group.

The author provides suggestions for further research that can develop IoT-based learning media with the STEM approach in other physics material to foster students' scientific work abilities and increase 4Cs (Critical thinking, Communication, Collaboration, and Creativity) skill in facing 21 st-century challenges.

\section{ACKNOWLEDGMENT}

Thanks to the head master of Senior High School 2 Batang, Central Java, to grant permission and support this research.

\section{AUTHOR CONTRIBUTIONS}

YRL and SL collected and analysed data. SL developing student worksheet products. S developing microcontroller and wrote the manuscript. All authors contributed in wrote the manuscript.

\section{REFERENCES}

Afrizal, M. A. (2018). Rancang bangun rumah pintar berbasis IoT (Internet of Things) sebagai media pembelajaran pada mata pelajaran pemrograman, mikroprosesor, dan mikrokontroller di SMKN 2 Surabaya. Jurnal Pendidikan Teknik Elektro, V. 07(1), 79-86.

Al Rikabi, H. T. S., Nasser, K. W., \& Alaidi, A. H. M. (2020). The application of wireless communication in IOT for saving electrical energy. International Journal of Interactive Mobile Technologies, 14(1), 152-160. https://doi.org/10.3991/ijim.v14i01.115
38

Ariyana, Y., Pudjiastuti, A., Bestary, R., \& Zamroni. (2019). Buku pegangan pembelajaran berorientasi pada keterampilan berpikir tingkat tinggi. Jakarta: Dirjen GTK Kemdikbud.

Artono, B., \& Putra, R. G. (2017). Penerapan internet of things (IoT) untuk kontrol lampu menggunakan arduino berbasis web. Jurnal Teknologi Informasi Dan Terapan, 5(1), 9-16. https://doi.org/10.25047/jtit.v5i1.73

Borg, W. R., \& Gall, M. D. (2003). Educational research: An introduction seventh edition. Boston: Pearson Education.

Charmonman, S., Mongkhonvanit, P., Ngoc Dieu, V., \& van der Linden, N. (2020). Applications of internet of things in elearning. International Journal of the Computer, the Internet and Management, 23(3), 1-4.

Dasilva, B. E., Ardiyati, T. K., Suparno, Sukardiyono, Eveline, E., Utami, T., \& Ferty, Z. N. (2019). Development of android-based interactive physics mobile learning media (IPMLM) with scaffolding learning approach to improve HOTS of high school students. Journal for the Education of Gifted Young Scientists, 7(3), 659-681. https://doi.org/10.17478/jegys.610377

Dinatha, N. M., \& Kua, M. Y. (2019). Pengembangan modul praktikum digital berbasis nature of science (NOS) untuk meningkatkan higher order thinking skill (HOTS). Journal of Education Technology, 3(4), 293-300.

Georgiou, H. (2014). Doing positive work: on student understanding of thermodynamics. The University of Sydney.

Georgious, H., \& Sharma, M. D. (2015). Does using active learning in thermodynamics lectures improve students' conceptual understanding and learning experiences? European Journal of Physics, 36(1). https://doi.org/10.1088/0143- 
0807/36/1/015020

Gómez, J., Huete, J. F., Hoyos, O., Perez, L., \& Grigori, D. (2013). Interaction system based on Internet of things as support for education. Procedia Computer Science, 21, 132-139. https://doi.org/10.1016/j.procs.2013.09. 019

Goovaerts, L., De Cock, M., Struyven, K., \& Dehaene, W. (2019). Developing a module to teach thermodynamics in an integrated way to 16 year old pupils. European Journal of STEM Education, 4(1), 1-11. https://doi.org/10.20897/ejsteme/3964

Hakim, A., Liliasari, L., Setiawan, A., \& Saptawati, G. A. P. (2017). Interactive multimedia thermodynamics to improve creative thinking skill of physics prospective teachers. Jurnal Pendidikan Fisika Indonesia, 13(1), 33-40. https://doi.org/10.15294/jpfi.v13i1.844 7

He, J. (Selena), Chia, D., Lo, T., Xie, Y., \& Lartigue, J. (2016). Integrating internet of things (IoT) into STEM undergraduate education: Case study of a modern technology infused courseware for embedded system course. Proceedings - Frontiers in Education Conference, FIE, 2016Novem, $1-9$. https://doi.org/10.1109/FIE.2016.77574 58

Holme, T. A., Luxford, C. J., \& Brandriet, A. (2015). Defining conceptual understanding in general chemistry. Journal of Chemical Education, 92(9), 1477-1483.

https://doi.org/10.1021/acs.jchemed.5b 00218

Kemdikbud. (2016). Silabus mata pelajaran sekolah menengah atas/madrasah aliyah (SMA/MA). Jakarta: Kementerian Pendidikan dan Kebudayaan.

Layali, S., \& Kartika, I. (2015). Pengembangan alat praktikum termodinamika berbasis problem based learning. Kaunia, XI(2), 136-143.
Malik, A., Novita, Y., \& Nuryantini, A. Y. (2019). Enhancing critical thinking skills of students related to temperature and heat topics through problem solving- laboratory model. Jurnal Penelitian \& Pengembangan Pendidikan Fisika, 5(1), 9-20. https://doi.org/10.21009/1.05102

Mohamed, F., Abdeslam, J., \& Lahcen, E. B. (2018). Towards new approach to enhance learning based on internet of things and virtual reality. $A C M$ International Conference Proceeding Series, 1-5. https://doi.org/10.1145/3230905.32309 55

Muchlis, F., Sulisworo, D., \& Toifur, M. (2015). Pengembangan alat peraga fisika berbasis internet of things untuk praktikum hukum II Newton. 6(1), 1-8.

Muchlis, F., Sulisworo, D., \& Toifur, M. (2017). Pengembangan alat peraga fisika berbasis internet of things. Jurnal Pendidikan Fisika Unversitas Muhammadiyah Makasar, 6(1), 13-20.

Prihatmoko, D. (2016). Penerapan internet of things (IoT) dalam pembelajaran di UNISNU Jepara. Simetris: Jurnal Teknik Mesin, Elektro Dan Ilmu Komputer, 7(2), 567-574. https://doi.org/10.24176/simet.v7i2.769 Purnamawati, D., Ertikanto, C., \& Suyatna, A. (2017). Keefektifan lembar kerja siswa berbasis inkuiri untuk menumbuhkan keterampilan berpikir tingkat tinggi. Jurnal Ilmiah Pendidikan Fisika Al-Biruni, 6(2), 209. https://doi.org/10.24042/jipfalbiruni.v6 i2.2070

Puspendik. (2019). Ringkasan Eksekutif hasil UN SMA/MA dan SMK tahun 2019. Jakarta: Kementerian Pendidikan dan Kebudayaan.

Religia, R., \& Achmadi, H. R. (2017). Pengembangan KIT sederhana stirling engine pada materi termodinamika sebagai media pembelajaran fisika SMA. Jurnal Inovasi Pendidikan Fisika, 6(3), 113-119. 
Saputra, R. H., \& Hertanto, D. B. (2018). Media berbasis teknologi internet of things (IoT) mata pelajaran teknik mikroprosesor di kelas $\mathrm{X}$ audio video SMK N 3 Yogyakarta. E-Journal Universitas Negeri Yogyakarta, 8(2), 131-138. Retrieved from http://journal.student.uny.ac.id/ojs

Saputro, V. C. E., Prabowo, \& Admoko, S. (2019). Pengembangan alat peraga mesin carnot sebagai media pembelajaran dengan model pembelajaran inkuiry terbimbing. $I P F$ : Inovasi Pendidikan Fisika, 08(02), 716721.

Saraubon, K. (2019). Learning media repository and delivery system for smart classrooms using IoT and mobile technologies. International Journal of Interactive Mobile Technologies, 13(2), 66-77.

https://doi.org/10.3991/ijim.v13i02.9941

Sari, D. M., Surantoro, \& Ekawati, E. Y. (2013). Analisis kesalahan dalam menyelesaikan soal materi termodinamika pada siswa SMA. Jurnal Materi Dan Pembelajaran Fisika (JMPF), 3(2), 33-39.

Subali, B., Lu, Z., \& Sumpono, I. (2019). Development of ultrasonic sensors based mechanical energy experiments. Jurnal Pendidikan Fisika Indonesia, 15(1), 29-38. https://doi.org/10.15294/jpfi.v15i1.193 08

Tatar, E., \& Oktay, M. (2011). The effectiveness of problem-based learning on teaching the first law of thermodynamics. Research in Science and Technological Education, 29(3), 315-332.

https://doi.org/10.1080/02635143.2011. 599318

Widoyoko, E. P. (2017). Teknik Penyusunan Instrumen Penelitian. (6 th ed). Yogyakarta: Pustaka Belajar.

Yani, A., Muhsyanur, Sahriah, Haerunnisa, \& Salmawati, S. (2018). Efektivitas pendekatan saintifik dengan media booklet higher order thinking terhadap hasil belajar biologi siswa SMA di kabupaten Wajo. Jurnal Biology Science \& Education, 7(1), 1-12.

Yono, N. T., Marpaung, M. A., \& Desnita, D. (2016). Pengembangan media pembelajaran termoelektrik generator sebagai sumber energi. Jurnal Penelitian \& Pengembangan Pendidikan Fisika, 02(2), 65-70. https://doi.org/10.21009/1.02209

Zimmermann, \& Torsten. (2018). Industry 4.0: Nothing is more steady than change. In Smart Grid Analytics for Sustainability and Urbanization. Hershey: IGI Global. 